\title{
Proyeksi Ekspor-Impor Non-Migas Indonesia ke Afrika Selatan
}

\author{
Kumara Jati ${ }^{1}$, Aziza Rahmaniar Salam ${ }^{2}$ \\ ${ }^{1,2}$ Badan Pengkajian dan Pengembangan Perdagangan, Kementerian Perdagangan \\ E-Mail: ${ }^{1}$ kumara_jati@yahoo.com; ${ }^{2}$ aziza@kemendag.go.id; Tel./ Fax: +62 23528694.
}

\begin{tabular}{ll}
\hline ARTIKEL INFO & \multicolumn{1}{c}{ ABSTRACT } \\
\hline $\begin{array}{l}\text { Keywords: Non-Oil and Gas } \\
\text { Export-Import, Indonesia, }\end{array}$ & $\begin{array}{l}\text { This study analyzes the projection of Indonesia's non-oil and gas exports and } \\
\text { imports to South Africa. Indonesia's trade policy needs to take into account } \\
\text { the seasonal and irregularity conditions of trade between Indonesia and } \\
\text { Time-Series Mtructural }\end{array} \quad \begin{array}{l}\text { South Africa. The The Structural Time-Series Model (STSM) shows that the } \\
\text { projected volume and value of Indonesia's non-oil and gas exports to South } \\
\text { Africa from } 2018 \text { to } 2027 \text { tends to stabilize with an upward trend. The } \\
\text { relevant authorities need to pay more attention to the seasonal trade patterns } \\
\text { where there is usually a fluctuation of exports and imports at the beginning } \\
\text { and end of the year from Indonesia to South Africa. In addition, relevan } \\
\text { stakeholders also need to anticipate if there is turmoil in overseas markets, } \\
\text { especially South Africa because it can affect the trade between the two } \\
\text { countries and the Indonesia economy in general. }\end{array}$
\end{tabular}

\section{PENDAHULUAN}

Perdagangan internasional didefinisikan sebagai transaksi dagang barang dan jasa antara subjek ekonomi satu negara dengan subjek ekonomi negara lain. Dalam penelitian ini kami hanya fokus pada perdagangan barang. Sedangkan subjek ekonomi yang dimaksud adalah penduduk yang terdiri dari warga negara biasa, perusahaan ekspor, perusahaan impor, perusahaan industri ataupun perusahaan negara. Perdagangan internasional terjadi akibat adanya perbedaan potensi sumber daya alam, sumber daya modal, sumber daya manusia dan kemajuan teknologi antar negara (Halwani 2005). Sedangkan menurut Dumairy (1997) perdagangan merupakan suatu proses pertukaran barang dan jasa yang dilakukan atas dasar suka sama suka, untuk memperoleh barang yang dibutuhkan. Dalam masa globalisasi, perdagangan tidak hanya dilakukan dalam satu negara saja. Bahkan dunia sudah memasuki perdagangan bebas. Hampir tidak ada satu negarapun yang tidak melakukan hubungan dengan negara lain.

Dalam perdagangan domestik para pelaku ekonomi bertujuan untuk memperoleh keuntungan dari aktivitas ekonomi yang dilakukannya. Demikian halnya dengan perdagangan internasional. Setiap negara yang melakukan perdagangan bertujuan mencari keuntungan dari perdagangan tersebut. Selain motif mencari keuntungan, Helpman dan Krugman (1991) mengungkapkan bahwa alasan utama terjadinya perdagangan internasional: neegara-negara berdagang karena mereka berbeda satu sama lain. Negara-negara melakukan perdagangan dengan tujuan untuk mencapai skala ekonomi (economic of scale).

Secara umum, perdagangan internasional terdiri dari kegiatan ekspor dan impor. Ekspor merupakan penjualan barang dan jasa yang dihasilkan oleh suatu negara ke negara lain, sebaliknya impor merupakan barang dan jasa yang masuk ke suatu negara. Negara yang memproduksi lebih dari kebutuhan dalam negerinya dapat mengekspor kelebihan produksi tersebut ke negara lain. Akan tetapi, negara yang tidak mampu memproduksi sendiri dapat mengimpor dari negara lain. Faktor yang memengaruhi perdagangan internasional dapat dilihat dari teori penawaran dan permintaan. Dari teori penawaran dan permintaan tersebut dapat ditarik kesimpulan bahwa perdagangan internasional dapat terjadi karena adanya kelebihan produksi suatu negara dengan kelebihan permintaan negara lain.

Sepengetahuan kami, belum banyak penelitian empiris sistematis yang berkaitan dengan proyeksi ekspor dan impor komoditi non-migas Indonesia ke negara Afrika Selata dengan Structural Time Series Model (STSM). Oleh karena itu, masih ada ruang untuk menyumbangkan penelitian agar 
bisa menambahkan referensi dalam literatur akademik dan bermanfaat bagi pemangku kepentingan terkait.

\section{Metode Proyeksi Ekspor dan Impor dengan Structural Time-Series Model (STSM)}

Volume dan Nilai ekspor dan impor non-migas Indonesia merupakan variabel yang tergolong dalam Volatile Variable (VV) atau variabel data yang relatif sulit dimodelkan. Oleh karena itu diperlukan model sederhana yang dapat menjelaskan dinamika VV. Salah satu cara untuk dapat melakukan penilaian dan proyeksi jangka pendek VV lebih terstruktur dan akurat adalah dengan melakukan dekomposisi dan proyeksi dalam sebuah model yang komprensif yaitu Structural TimeSeries Model (STSM) Decomposition (Harvey dan Shephard, 1993).

Kelebihan dari pendekatan STSM ini dibandingkan rata-rata historis variabel yaitu lebih terstruktur, dapat memodelkan pola musiman dan ketidakteraturan variabel (irregularity) serta membuat modelnya lebih robust (kuat). STSM Decomposition (Harvey dan Peters, 1990; Durbin dan Koopman, 2001) ini terdiri dari 3 komponen yaitu:

Komponen Trend yang mengikuti proses random walk.

$$
\begin{aligned}
& \tau_{t}=\mu_{t}+\tau_{t-1}+n_{t}, n_{t} \sim N\left(0, \sigma_{\eta}^{2}\right) \\
& \mu_{t}=\mu_{t-1}+v_{t} \sim N\left(0, \sigma_{v}^{2}\right)
\end{aligned}
$$

Dimana $\mathrm{G}_{t}$ adalah komponen trend, $\mu_{t}$ adalah slope yang dapat bersifat stochastic, dan $n_{t}$ adalah error dari $\mathrm{G}_{t}$, serta $U_{t}$ adalah error dari $\mu_{t}$.

(1) Komponen Musiman yang spesifikasi $\left(y_{t}\right)$ mengikuti model trigonometri.

$\left[\begin{array}{c}\gamma_{j, t} \\ \gamma_{j, t}^{*}\end{array}\right]=\left[\begin{array}{cc}\cos \lambda_{j} & \sin \lambda_{j} \\ -\sin \lambda_{j} & \cos \lambda_{j}\end{array}\right]\left[\begin{array}{c}\gamma_{j, t-1} \\ \gamma_{j, t-1}^{*}\end{array}\right]+\left[\begin{array}{c}\omega_{t} \\ \omega_{t}^{*}\end{array}\right]$

untuk $j=1, \ldots,[s / 2] ; \quad t=1, \ldots, T$. Dimana $\gamma_{t}$ adalah komponen musiman, $\omega_{t}$ adalah error dari $\gamma_{t}$.

(2) Komponen Siklus yang modelnya menyerupai Komponen Musiman.

$\left[\begin{array}{l}\psi_{j, t} \\ \psi_{j, t}^{*}\end{array}\right]=\rho \psi\left[\begin{array}{cc}\cos \lambda_{c} & \sin \lambda_{c} \\ -\sin \lambda_{c} & \cos \lambda_{c}\end{array}\right]\left[\begin{array}{l}\psi_{j, t-1} \\ \psi_{j, t-1}^{*}\end{array}\right]+\left[\begin{array}{l}K_{t} \\ K_{t}^{*}\end{array}\right]$

untuk $t=1, \ldots, T$. Dimana $\psi_{t}$ adalah komponen siklus, $\rho_{\psi}$ dan $\lambda_{c}$ adalah faktor damping dan frekuensi dengan nilai $0<\rho_{\psi} \leq 1$ dan $0 \leq \lambda_{c} \leq \pi$ sementara $K_{t}$ dan $K_{t}^{*}$ tidak terkorelasi secara mutual $N\left(0, \sigma_{k}^{2}\right)$. Jika ketiga komponen tersebut dijumlahkan maka menjadi:

$$
y_{t}=\tau_{t}+\gamma_{t}+\psi_{t}+\varepsilon_{t}
$$

Jadi $y_{t}$ adalah variabel ekspor dan impor yang diproyeksi oleh komponen trend $\left(\mathrm{G}_{t}\right)$, musiman $\left(\gamma_{t}\right)$ dan siklus $\left(\psi_{t}\right)$. Model ini diestimasi dengan metode MLE (Maximum Likelihood Estimation) dan 3 komponen yang sulit untuk diestimasi yang dihasilkan dari Kalman filter (Harvey dan Shephard, 1993). Pengambilan data untuk model ini didapat dari Badan Pusat Statistik (BPS). Periode data yang digunakan yaitu data bulanan dari minggu pertama Maret 2013 - minggu ketiga Januari 2018. Software yang digunakan dalam penelitian ini menggunakan Stamp OxMetrics 7. 


\section{Proyeksi Perkembangan Volume Ekspor Non-Migas Indonesia ke Afrika Selatan}

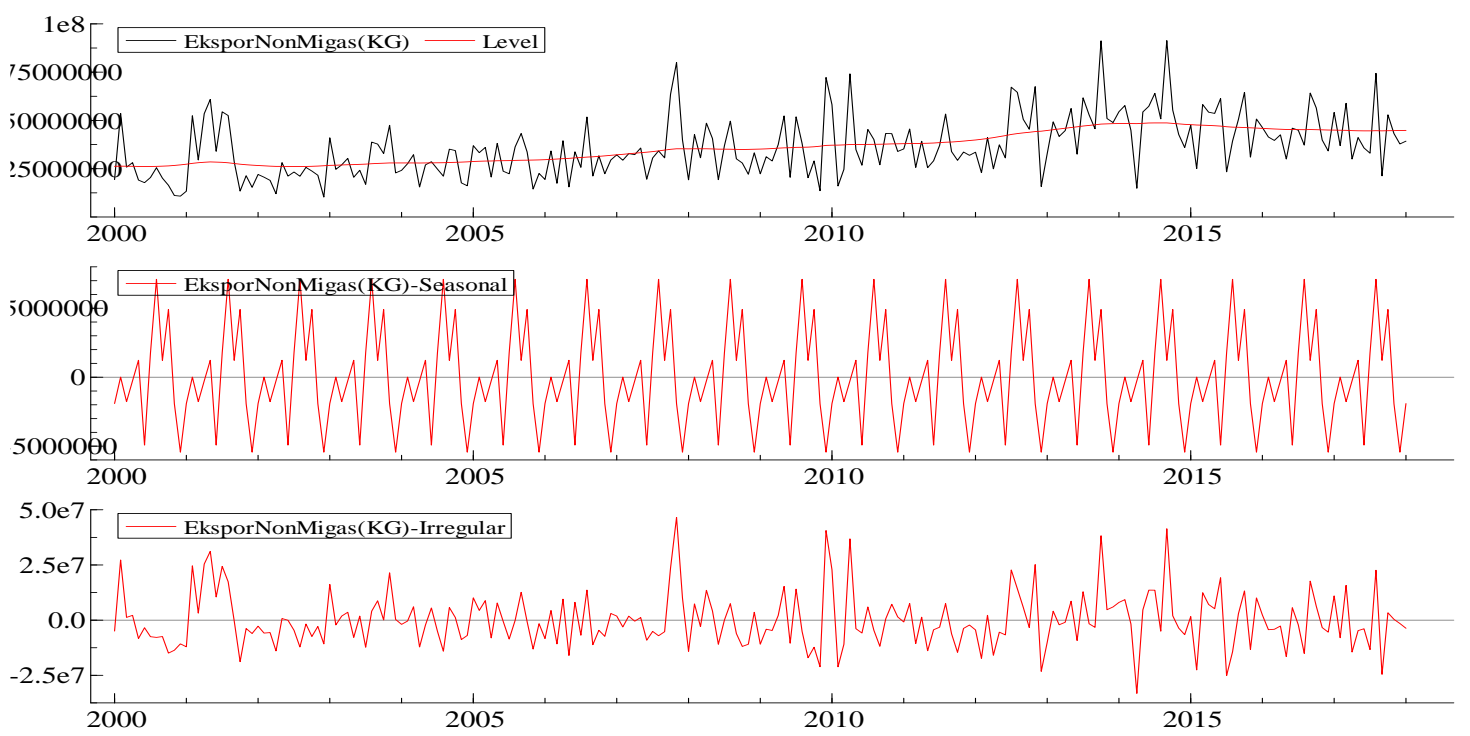

Sumber: hasil penghitungan software Stamp OxMetrics 7, diolah

\section{Gambar 1. Perkembangan Volume Ekspor Non-Migas Indonesia dan Pengaruh Komponen Trend, Seasonal dan Irregularity}

Pendekatan Structural Time Series Model (STSM) terhadap perkembangan volume ekspor non-migas Indonesia ke Afrika Selatan menunjukkan bahwa : (1) dinamika volume ekspor non-migas Indonesia bersumber dari tingginya komponen trend, seasonal dan irregularity, (2) komponen seasonal volume ekspor non-migas cenderung berfluktuasi dengan nilai yang rendah pada bulan Januari-Mei dan nilai positif pada bulan Juni-Oktober, serta berubah rendah lagi pada blan NovemberDesember, (3) adanya komponen irregularity dengan nilai terendah terjadi pada awal tahun 2014 dan pertengahan tahun 2014 serta nilai tertinggi pada awal tahun 2008, 2010, 2014 (Gambar 1). Irregularities yang terjadi diperkirakan karena adanya penurunan dan peningkatan produktivitas komoditi ekspor unggulan Indonesia seperti kelapa sawit, produk otomotif, sepatu, kakao, bahan kimia dan produk karet.

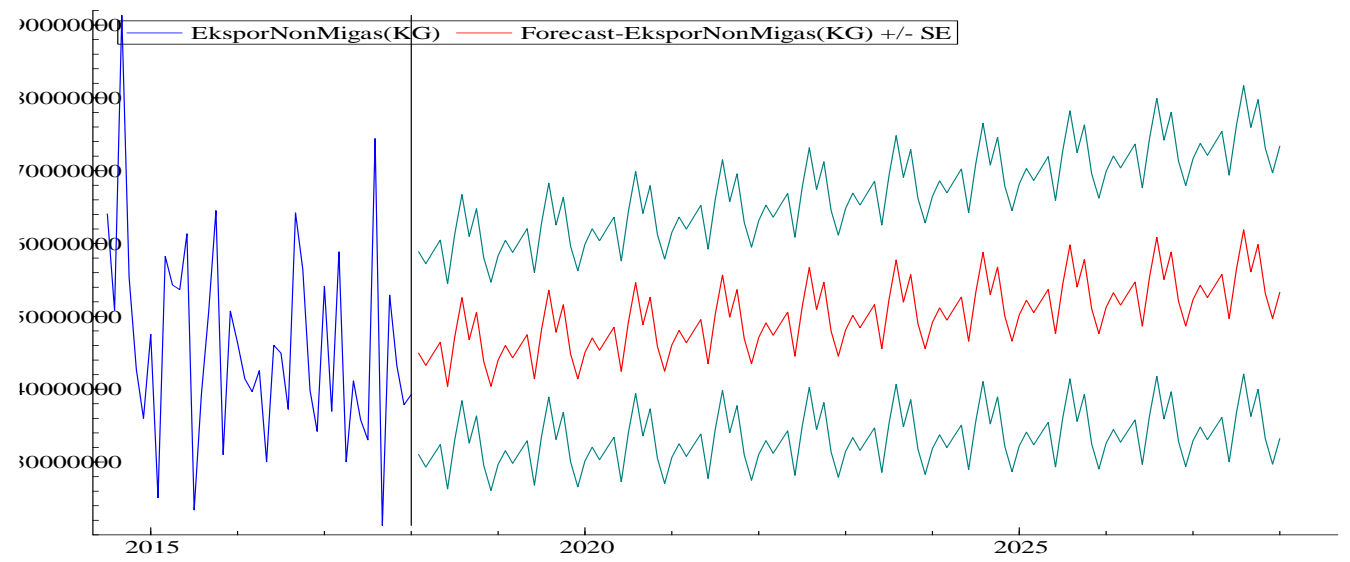

Sumber: hasil penghitungan software Stamp OxMetrics 7, diolah

Gambar 2. Proyeksi Volume Ekspor Non-Migas Indonesia 
Vol. 1, No. 1, Juni 2018, pp. 120-127

Tabel 1. Proyeksi Volume Ekspor Non-Migas Indonesia

\begin{tabular}{|r|r|r|}
\hline Tahun & Ekspor Non Migas (Ton) & \% Perubahan Volume Ekspor Non Migas \\
\hline 2018 & 540.513 & 3,0 \\
\hline 2019 & 556.616 & 2,2 \\
\hline 2020 & 569.032 & 2,2 \\
\hline 2021 & 581.449 & 2,1 \\
\hline 2022 & 593.865 & 2,1 \\
\hline 2023 & 606.282 & 2,0 \\
\hline 2024 & 618.699 & 2,0 \\
\hline 2025 & 631.115 & 2,0 \\
\hline 2026 & 643.532 & 1,9 \\
\hline 2027 & 655.948 & $\mathbf{2 1 , 4}$ \\
\hline \multicolumn{2}{|r|}{ Perubahan 2018 - 2027 } & $\mathbf{6 , 4}$ \\
\hline \multicolumn{2}{|r|}{ Koefisien Keragaman } &
\end{tabular}

Sumber: hasil penghitungan software Stamp OxMetrics 7, diolah (data tahun 2018-2027 hasil proyeksi)

Koefisien Keragaman = standar deviasi dibagi rata-rata, jika dibawah 9 maka stabil .

Berdasarkan gambar 2 dan tabel 1 terlihat bahwa proyeksi volume ekspor non-migas Indonesia diperkirakan memiliki trend meningkat. Setiap tahun diproyeksi volume ekspor Indonesia akan meningkat dengan \% perubahan selalu positif dengan angka peningkatan paling tinggi sebesar $3 \%$ di tahun 2019 dan peningkatan paling rendah terjadi di tahun 2027 sebesar 1,9\%. Jadi proyeksi perubahan volume ekspor non-migas Indonesia dari tahun 2018 ke tahun 2027 sebesar 21,4\%. Nilai Koefisien Keragaman atau fluktuasi peningkatan ekspor diperkirakan sebesar 6,4\% atau relatif stabil.

\section{Proyeksi Perkembangan Nilai Ekspor Non-Migas Indonesia ke Afrika Selatan}

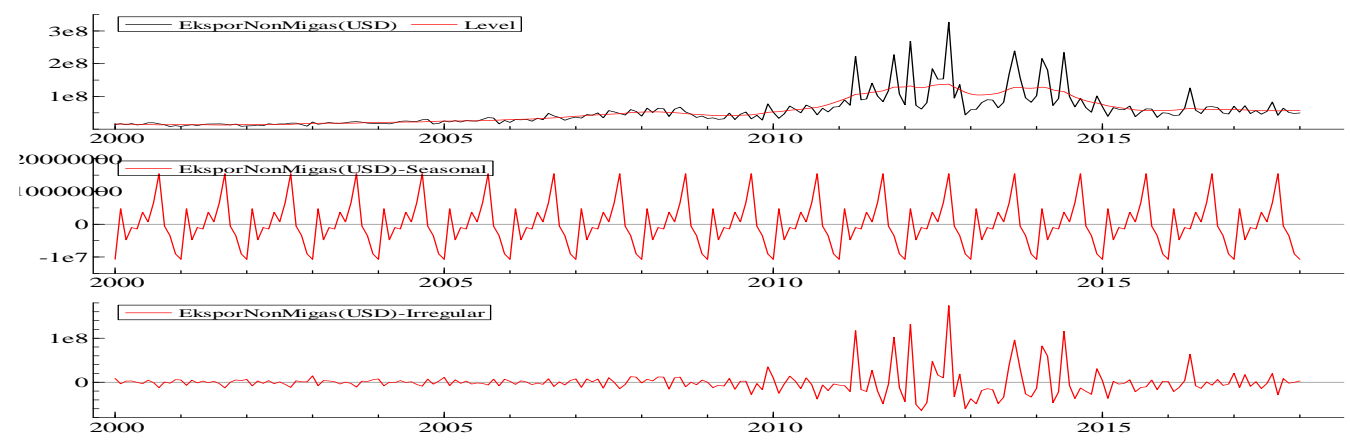

Sumber: hasil penghitungan software Stamp OxMetrics 7, diolah

\section{Gambar 3. Perkembangan Nilai Ekspor Non-Migas Indonesia dan Pengaruh Komponen Trend, Seasonal dan Irregularity}

Pendekatan Structural Time Series Model (STSM) terhadap perkembangan nilai ekspor nonmigas Indonesia menunjukkan bahwa: (1) dinamika nilai ekspor non-migas Indonesia bersumber dari tingginya komponen trend, seasonal dan irregularity, (2) komponen seasonal nilai ekspor non-migas cenderung berfluktuasi dengan nilai rendah dan tinggi menyerupai perkembangan volume ekspor nonmigas Indonesia, (3) adanya komponen irregularity dengan nilai yang berfluktuasi terjadi pada tahun 2012-2014. 
Sumber: hasil penghitungan software Stamp OxMetrics 7, diolah

Gambar 4. Proyeksi Nilai Ekspor Non-Migas Indonesia

Tabel 2. Proyeksi Nilai Ekspor Non-Migas Indonesia

\begin{tabular}{|r|r|r|r|}
\hline Tahun & Ekspor Non Migas (Ribu USD) & \% Perubahan Nilai Ekspor Non Migas & \\
\hline 2018 & 703.881 & 3,5 \\
\hline 2019 & 728.628 & 3,8 \\
\hline 2020 & 756.306 & 3,7 \\
\hline 2021 & 783.984 & 3,5 \\
\hline 2022 & 811.662 & 3,4 \\
\hline 2023 & 839.340 & 3,3 \\
\hline 2024 & 867.018 & 3,2 \\
\hline 2025 & 894.696 & 3,1 \\
\hline 2026 & 922.373 & 3,0 \\
\hline 2027 & 950.051 & $\mathbf{3 5 , 0}$ \\
\hline & & & $\mathbf{1 0 , 1}$ \\
\hline
\end{tabular}

Sumber: hasil penghitungan software Stamp OxMetrics 7, diolah

(data tahun 2018-2027 hasil proyeksi) Koefisien Keragaman = standar deviasi dibagi rata-rata, jika diatas 9 maka relatif fluktuasi.

Berdasarkan gambar 4 dan tabel 2 terlihat bahwa proyeksi nilai ekspor non-migas Indonesia diperkirakan memiliki trend meningkat namun dengan tingkat kemiringan yang lebih rendah dibandingkan volume ekspor non-migas Indonesia. Setiap tahun diproyeksi nilai ekspor Indonesia akan meningkat dengan \% perubahan selalu positif dengan angka peningkatan paling tinggi sebesar 3,8\% di tahun 2020 dan peningkatan paling rendah terjadi di tahun 2027 sebesar 3\%. Jadi proyeksi perubahan nilai ekspor non-migas Indonesia dari tahun 2018 ke tahun 2027 sebesar 35\%. Nilai Koefisien Keragaman atau fluktuasi peningkatan ekspor diperkirakan sebesar 10,1\% atau relatif berfluktuasi.

\section{Proyeksi Perkembangan Volume Impor Non-Migas Indonesia ke Afrika Selatan}

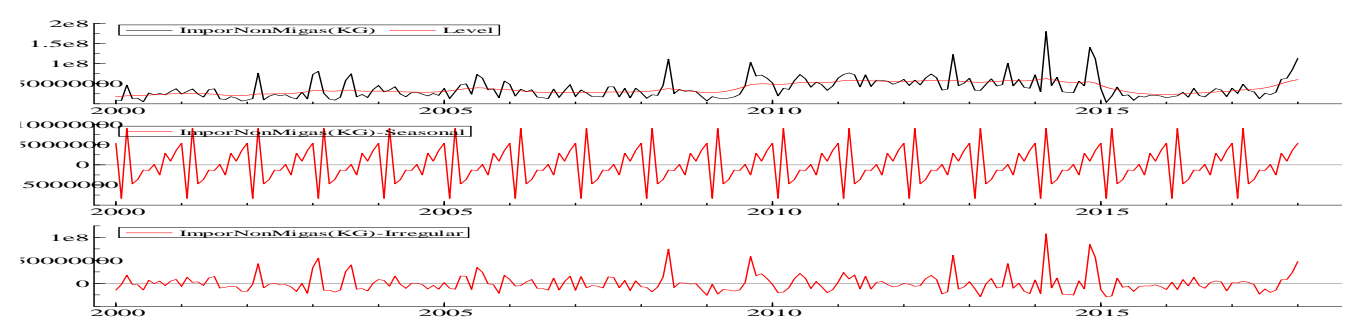

Sumber: hasil penghitungan software Stamp OxMetrics 7, diolah

Gambar 5. Perkembangan Volume Impor Non-Migas Indonesia dan Pengaruh Komponen Trend, Seasonal dan Irregularity 
Pendekatan Structural Time Series Model (STSM) terhadap perkembangan volume impor nonmigas Indonesia menunjukkan bahwa: (1) dinamika volume impor non-migas Indonesia bersumber dari tingginya komponen trend, seasonal dan irregularity, (2) komponen seasonal volume impor nonmigas cenderung berfluktuasi pada awal tahun, lalu rendah di bulan Maret-Mei, kemudian tinggi di bulan Juni-Oktober, lalu berfluktuasi lagi di akhir tahun, (3) adanya komponen irregularity dengan nilai paling tinggi di tahun 2008 dan 2014. Hal ini diperkirakan terjadi karena di tahun 2008 ada efek dari global economic crisis sedangkan tahun 2014 terjadi penurunan harga komoditi termasuk harga minyak mentah dunia yang bisa berakibat tidak langsung terhadap volume impor non-migas Indonesia. Produk unggulan ekspor Afrika Selatan ke Indonesia diantaranya yaitu bubuk kayu, alumunium, buahbuahan dan tembaga.

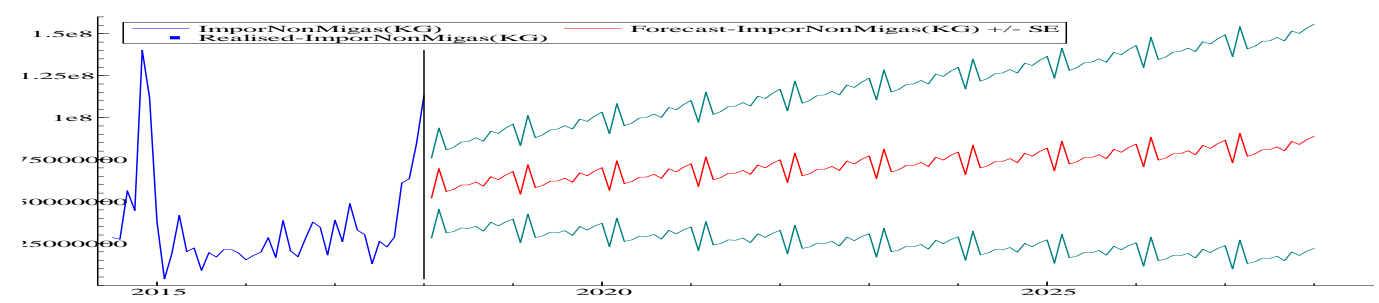

Sumber: hasil penghitungan software Stamp OxMetrics 7, diolah

Gambar 6. Proyeksi Volume Impor Non-Migas Indonesia

Tabel 3. Proyeksi Volume Impor Non-Migas Indonesia

\begin{tabular}{|r|c|c|}
\hline Tahun & Impor Non-Migas (Ton) & \% Perubahan Nilai Impor Non-Migas \\
\hline 2018 & 781.922 & \\
\hline 2019 & 762.171 & $-2,5$ \\
\hline 2020 & 790.190 & 3,7 \\
\hline 2021 & 818.210 & 3,5 \\
\hline 2022 & 846.229 & 3,4 \\
\hline 2023 & 874.248 & 3,3 \\
\hline 2024 & 902.267 & 3,2 \\
\hline 2025 & 930.287 & 3,1 \\
\hline 2026 & 958.306 & 3,0 \\
\hline 2027 & 986.325 & 2,9 \\
\hline \multicolumn{2}{|r|}{ Perubahan 2018- 2027 } & $\mathbf{2 6 , 1}$ \\
\hline Koefisien Keragaman & $\mathbf{9 , 0}$ \\
\hline
\end{tabular}

Sumber: hasil penghitungan software Stamp OxMetrics 7, diolah (data tahun 2018-2027 hasil proyeksi)

Koefisien Keragaman = standar deviasi dibagi rata-rata, jika diatas 9 maka relatif fluktuasi .

Berdasarkan gambar 6 dan tabel 3 terlihat bahwa proyeksi volume impor non-migas Indonesia ke Afrika Selatan diperkirakan memiliki trend meningkat dengan tingkat kemiringan menyerupai proyeksi volume ekspor non-migas Indonesia tetapi relatif lebih tinggi dibandingkan dengan proyeksi nilai ekspor non-migas Indonesia. Setiap tahun diproyeksi volume impor non-migas Indonesia akan meningkat kecuali pada tahun 2019 terjadi penurunan sebesar 2,5\%. Peningkatan volume impor nonmigas terbesar diperkirakan terjadi tahun 2020 sebesar 3,7\% dan peningkatan terendah diperkirakan terjadi tahun 2027 sebesar 2,9\%. Jadi proyeksi perubahan volume impor non-migas Indonesia dari tahun 2018 ke tahun 2027 sebesar 26,1\%. Nilai Koefisien Keragaman atau fluktuasi peningkatan volume impor non-migas diperkirakan sebesar $9 \%$ atau relatif berfluktuasi. 


\section{Proyeksi Perkembangan Nilai Impor Non-Migas Indonesia ke Afrika Selatan}

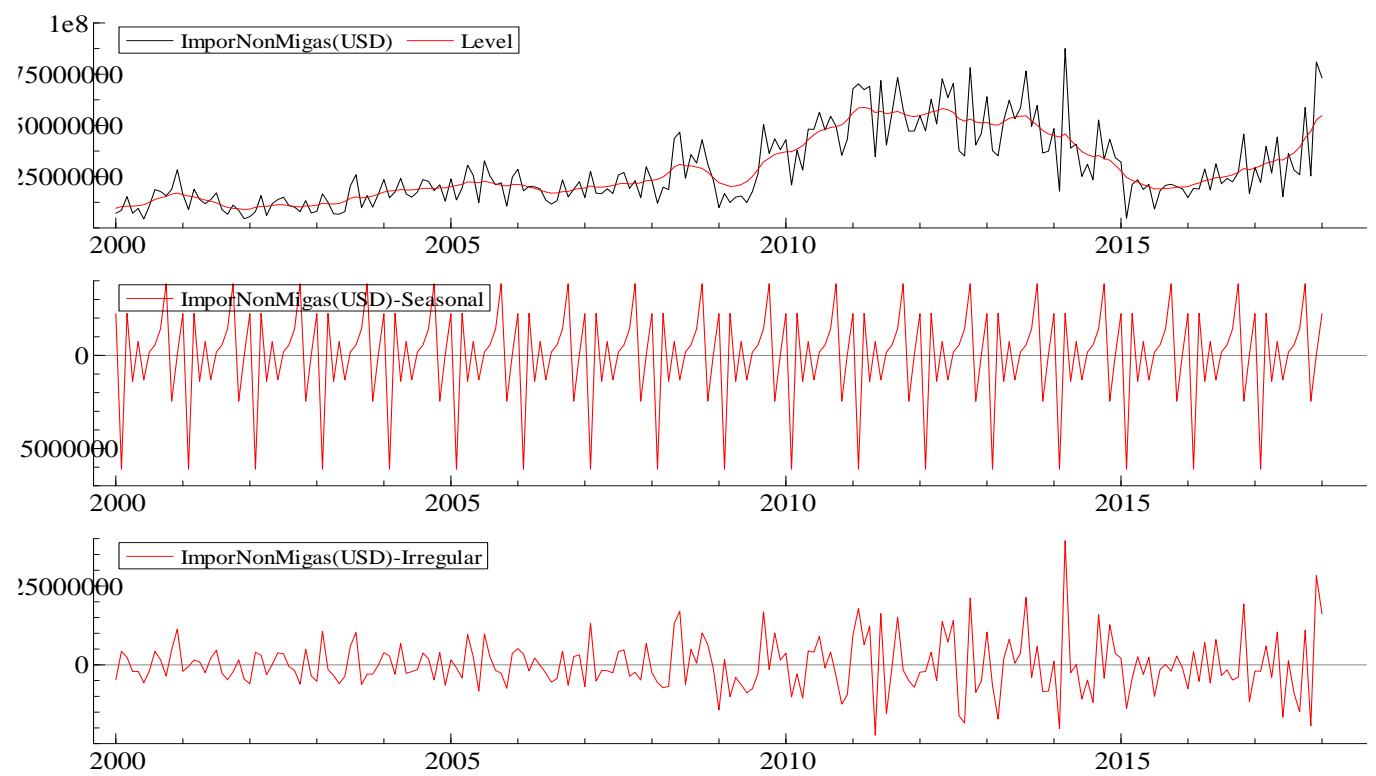

Sumber: hasil penghitungan software Stamp OxMetrics 7, diolah

Gambar 7. Perkembangan Nilai Impor Non-Migas Indonesia dan Pengaruh Komponen Trend, Seasonal dan Irregularity

Pendekatan Structural Time Series Model (STSM) terhadap perkembangan nilai impor nonmigas Indonesia ke Afrika Selatan menunjukkan bahwa: (1) dinamika nilai impor non-migas Indonesia menunjukkan bahwa: (1) dinamika nilai impor non-migas Indonesia bersumber dari komponen trend, seasonal dan irregularity, (2) komponen seasonal nilai impor non-migas cenderung berfluktuasi dengan pola menyerupai perkembangan volume impor non-migas Indonesia, (3) adanya komponen irregularity relatif stabil di tahun 2000-2011, tetapi berfluktuasi dengan nilai paling tinggi di tahun 2014 dan nilai paling rendah terjadi di tahun 2012, 2013, 2014 dan 2017.

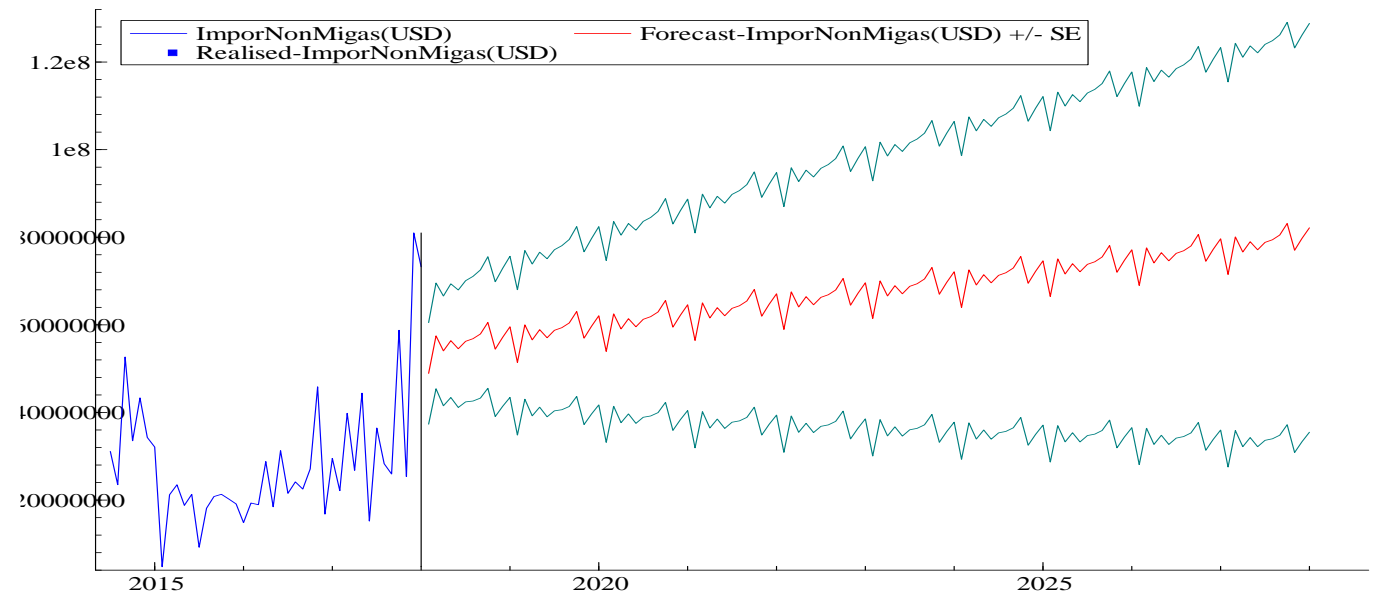

Sumber: hasil penghitungan software Stamp OxMetrics 7, diolah

Gambar 8. Proyeksi Nilai Impor Non-Migas Indonesia ke Afrika Selatan 
Vol. 1, No. 1, Juni 2018, pp. 120-127

Tabel 4. Proyeksi Nilai Impor Non-Migas Indonesia ke Afrika Selatan

\begin{tabular}{|r|r|r|r|}
\hline Tahun & Impor Non-Migas (Ribu USD) & \% Perubahan Nilai Impor Non-Migas \\
\hline 2018 & 687.838 & 2,0 \\
\hline 2019 & 701.770 & 4,3 \\
\hline 2020 & 731.889 & 4,1 \\
\hline 2021 & 762.008 & 4,0 \\
\hline 2022 & 792.128 & 3,8 \\
\hline 2023 & 822.247 & 3,7 \\
\hline 2024 & 852.366 & 3,5 \\
\hline 2025 & 882.485 & 3,4 \\
\hline 2026 & 912.604 & 3,3 \\
\hline 2027 & 942.723 & $\mathbf{3 7 , 1}$ \\
\hline & & $\mathbf{1 1 , 0}$ \\
\hline
\end{tabular}

Sumber: hasil penghitungan software Stamp OxMetrics 7, diolah(data tahun 2018-2027 hasil proyeksi) Koefisien Keragaman = standar deviasi dibagi rata-rata, jika diatas 9 maka relatif fluktuasi .

Berdasarkan gambar 8 dan tabel 4 terlihat bahwa proyeksi nilai impor non-migas Indonesia ke Afrika Selatan diperkirakan memiliki trend meningkat dengan kemiringan menyerupai proyeksi volume ekspor dan volume impor non-migas Indonesia. Setiap tahun diproyeksi nilai impor non-migas Indonesia diperkirakan meningkat dengan nilai peningkatan terendah di tahun 2019 sebesar 2\%, serta tertinggi terjadi di tahun 2020 sebesar 4,3\%. Jadi proyeksi perubahan nilai impor non-migas Indonesia dari tahun 2018 ke tahun 2027 sebesar 37,1\%. Nilai Koefisien Keragaman atau fluktuasi peningkatan nilai impor non-migas diperkirakan sebesar $11 \%$ atau relatif berfluktuasi.

\section{KESIMPULAN}

Proyeksi volume dan nilai ekspor dan impor non-migas Indonesia ke Afrika Selatan secara umum memiliki trend meningkat dari 2018 sampai dengan tahun 2027. Proyeksi peningkatan terbesar terjadi pada proyeksi nilai impor non-migas Indonesia ke Afrika Selatan dari tahun 2018 sampai tahun 2027 sebesar 37\%, sedangkan proyeksi peningkatan terendah terjadp pada proyeksi volume ekspor non-migas yaitu sebesar $21,4 \%$. Temuan yang sama terjadi pada perhitungan Koefisien Keragaman (KK), angka terbesar untuk keempat variabel yang diproyeksi yaitu $11 \%$ untuk nilai impor non-migas Indonesia ke Afrika Selatan, sedangkan angka KK terendah yaitu 6,1\% untuk volume ekspor nonmigas Indonesia ke Afrika Selatan. Angka KK atau fluktuasi nilai dan volume impor diatas nilai 9\% patut diantisipasi apabila memang barang yang diimpor merupakan barang konsumsi, apabila barang yang diimpor merupakan bahan baku dan barang modal perlu dipastikan bahwa ada peningkatan nilai tambah yang terjadi sehingga manfaat tersebut bisa didapat oleh masyarakat Indonesia baik dalam penyerapan tenaga kerja maupun kesejahteraan ekonomi.

\section{DAFTAR PUSTAKA}

Dumairy. (1997). Perekonomian Indonesia. Penerbit Erlangga. Jakarta.

Durbin, J., \& Koopman, S. J. (2001). Time Series Analysis by State Space Methods. https://doi.org/10.1093/acprof:oso/9780199641178.001.0001

Halwani, R.Hendra. (2005). Ekonomi Internasional dan Globalisasi Ekonomi. Ghalia Indonesia. Bogor.

Harvey, A.C. dan Shephard, N. 1993. Structural Time Series Models. Handbook of Statistics, Vol.11, Elsevier Science.

Harvey, A., \& Peters, S. (1990). Estimation procedures for structural time series models. Journal of Forecasting, 9(2), 89-108. https://doi.org/10.1002/for.3980090203

Helpman, E. and P. Krugman. (1991). Trade Policy and Market Structure. Cambridge, MIT Press. 